\title{
Efficacy of Four Soil Treatments Against Fusarium oxysporum f. sp. vasinfectum Race 4 on Cotton
}

R. S. Bennett, D. W. Spurgeon, and W. R. DeTar, Western Integrated Cropping Systems Research Unit, USDA-ARS, Shafter, CA 93263; J. S. Gerik, San Joaquin Valley Agricultural Sciences Center, Parlier, CA 93648; R. B. Hutmacher, Department of Plant Sciences, University of California, Davis 95616; and B. D. Hanson, San Joaquin Valley Agricultural Sciences Center, Parlier, CA 93648

\begin{abstract}
Bennett, R. S., Spurgeon, D. W., DeTar, W. R., Gerik, J. S., Hutmacher, R. B., and Hanson, B. D. 2011. Efficacy of four soil treatments against Fusarium oxysporum f. sp. vasinfectum race 4 on cotton. Plant Dis. 95:967-976.

Fusarium wilt, caused by race 4 of Fusarium oxysporum f. sp. vasinfectum, is a critically important disease problem in California cotton (Pima, Gossypium barbadense; Upland, G. hirsutum). Because few cultivars with resistance to race 4 are available, alternative management strategies for this disease are needed. Four soil treatments (50:50 methyl-bromide + chloropicrin as a positive control; 60:40 chloropicrin + 1,3-dichloropropene; 6 weeks of solarization; and metam-sodium) were evaluated for efficacy against race 4 in a naturally infested, heavy clay soil. Treatments were evaluated based on plant mortality, height, number of mainstem nodes, vascular discoloration ratings, and soil counts of $F$. oxysporum. Two cultivars each of Pima and Upland cotton varying in resistance to race 4 were used. Plant mortality was lowest in methyl-bromide + chloropicrin, solarization, and chloropicrin + 1,3-dichloropropene treatments, and highest in

the nontreated and metam-sodium treatments. Although most plant mortality occurred within 5 weeks after planting, substantial mortality of the susceptible Pima cultivar DP 744 accumulated for up to 10 weeks. Seven to eight weeks after planting, plants in methyl-bromide + chloropicrin and chloropicrin + 1,3-dichloropropene treatments were taller and had more mainstem nodes than in other treatments. Vascular discoloration was reduced in methyl-bromide + chloropicrin and solarization treatments compared with the nontreated control, metamsodium, and chloropicrin $+1,3$-dichloropropene treatments. Soil counts of $F$. oxysporum were significantly reduced only in the methylbromide + chloropicrin, chloropicrin + 1,3-dichloropropene, and solarization treatments. Six weeks of solarization and 60:40 chloropicrin + 1,3-dichloropropene (295 liters a.i./ha) proved effective for reducing Fusarium wilt of cotton in heavy clay soil.
\end{abstract}

Fusarium wilt, caused by race 4 of Fusarium oxysporum Schltd.:Fr. f. sp. vasinfectum (Atk.) W.C. Snyd. \& H.N. Hans., has become a major disease of cotton (Gossypium spp.) in California. Race 4 was first detected in this state in 2001, when severe loss to Fusarium wilt was observed in a field with clay loam soil. Races 1 and 2 of $F$. oxysporum f. sp. vasinfectum were known to be present in California (20), but Fusarium wilt caused by these races generally occurs in sandy or sandy loam soils infested with root-knot nematodes, Meloidogyne incognita (Kofoid \& White) Chitwood $(8,12,17)$. Previously, race 4 had been found only in Asia $(1,10,23,32)$. Since its discovery in California, race 4 has spread to most cotton production areas in the San Joaquin Valley.

Availability of economically practical options for managing Fusarium wilt of cotton (7) is limited. Fusarium wilt caused by nematode-associated races of $F$. oxysporum $\mathrm{f}$. sp. vasinfectum may be managed by minimizing populations of the root-knot nematode through soil fumigation, crop rotation, and use of nematode-resis-

Corresponding author: R. S. Bennett, E-mail: rebecca.bennett@ars.usda.gov

Current address of B. D. Hanson: Department of Plant Sciences, University of California, Davis 95616.

Mention of trade names or commercial products in this article is solely for the purpose of providing specific information and does not imply recommendation or endorsement by the U.S. Department of Agriculture. The U.S. Department of Agriculture is an equal opportunity provider and employer.

* The $e$-Xtra logo stands for "electronic extra" and indicates that one supplementary table and one supplementary figure are available online.

Accepted for publication 14 March 2011.

doi:10.1094/PDIS-09-10-0696

This article is in the public domain and not copyrightable. It may be freely reprinted with customary crediting of the source. The American Phytopathological Society, 2011. tant cultivars $(19,24,29)$. The ability of root-knot nematodes to affect crops rotated with cotton $(24,31)$ provides additional incentive for managing nematode populations. However, management of Fusarium wilt caused by races not associated with nematodes, such as race 4 and the Australian genotypes of $F$. oxysporum f. sp. vasinfectum, is more difficult. In California, host resistance has been the primary tactic for managing race 4 despite the limited number of cultivars with useful levels of resistance $(16,34)$. In 2008 , nearly three-quarters of the Pima ( $G$. barbadense L.) production in California was planted to a single cultivar with race 4 resistance (Phytogen 800, Dow AgroSciences) (35). Although Phytogen 800 and a recently released race 4-resistant cultivar, Phytogen 805RF, are widely planted in California, resistance in both cultivars to race 4 is incomplete. Fields planted with Phytogen 800 and 805RF occasionally exhibit significant plant loss to Fusarium wilt (R. B. Hutmacher and R. S. Bennett, unpublished data). Most other commercial Pima cultivars are highly susceptible to race 4 and increase soilborne inoculum if planted (15). To date, Upland ( $G$. hirsutum L.) cultivars have demonstrated only moderate resistance to race 4 (16).

While host resistance is the most economical strategy for managing Fusarium wilt of cotton, the limited selection of resistant cultivars indicates the need for other management options. Chemigation (3) and solarization (soil heating under transparent plastic film) $(4,21)$ to reduce soilborne inoculum are usually considered too costly for cotton production. However, use of these approaches may be warranted in small disease hotspots to prevent further spread of inoculum, especially if the benefits persist over multiple seasons or reduce weeds or disease in rotation crops. Relatively costly fumigants, such as methyl-bromide, chloropicrin, and 1,3-dichloropropene, have been widely used to manage Fusarium wilt and other soilborne diseases in high-value crops $(5,13,14,26)$. In California, metam-sodium and 6 weeks of solarization were evaluated individually and in combination for controlling Fusarium wilt of cotton (3). Ben-Yephet and colleagues found that neither of two rates of metam-sodium (151 and 303 
$\mathrm{kg} / \mathrm{ha}$ ) nor 6 weeks of solarization reduced $F$. oxysporum f. sp. vasinfectum inoculum by more than half relative to the nontreated plots. In contrast, plots treated with $303 \mathrm{~kg} / \mathrm{ha}$ of metam-sodium, applied in combination with solarization in July through August, reduced propagules to $5 \%$ of the numbers observed in nontreated plots (3). The same researchers found that solarization applied using a double layer of polyethylene film reduced $F$. oxysporum $\mathrm{f}$. sp. vasinfectum inoculum levels to $2.5 \%$ of pretreatment levels after just 31 days (4). In Israel, 7 weeks of solarization significantly reduced soilborne inoculum levels of $F$. oxysporum $\mathrm{f}$. sp. vasinfectum, and successive plantings of cotton exhibited reduced levels of disease for as long as 3 years $(22)$. These studies $(3,4,22)$ were conducted with races 1,2 , or 3 of $F$. oxysporum f. sp. vasinfectum $(20,28)$. To our knowledge, no soil treatments have been evaluated against race 4 . Our objective was to evaluate soil treatments for reducing inoculum levels of $F$. oxysporum f. sp. vasinfectum race 4 in heavy clay soil.

\section{Materials and Methods}

Two experiments were conducted in consecutive years (2007, 2008) in adjacent portions of a commercial field infested with race 4 of $F$. oxysporum f. sp. vasinfectum in Kern County, CA. The experimental designs and procedures were the same for both experiments except where specifically noted. The soil type was Buttonwillow (clayey over loamy, smectitic, nonacid, thermic Vertic Torrifluvent) and Lokern (fine, smectitic, nonacid, thermic Vertic Torrifluvents) clay (27\% sand, 33\% silt, $40 \%$ clay), and the field had no known history of fumigation. The field was planted to cotton for 3 years before the experiments were initiated. In the cotton crop prior to the experiment, $F$. oxysporum f. sp. vasinfectum was isolated from diseased plants and confirmed as race 4 using race-specific polymerase chain reaction (PCR) primers ( $\mathrm{R}$. Bennett, unpublished; 36). Each experiment used a randomized block design with unequal replication and a hierarchical design structure. Blocks were arranged to account for a gradient in disease symptoms observed in the previous cotton crop. Soil treatments were randomly assigned to whole plots, and cotton cultivars, replicated twice within whole plots, were assigned to subplots. Replicates of cotton cultivars were treated as subsamples. Soil treatments were replicated four to five times in experiment 1 and five to seven times in experiment 2 . A visual assessment of the cotton crop prior to the experiments indicated the area selected for experiment 2 had less disease than the area for experiment 1 . Consequently, inoculum levels of race 4 were augmented (15) in experiment 2 by growing a susceptible cultivar (DP 340, Delta and Pine Land Company) in 2007.

Soil treatments. Each whole plot was $15.24 \mathrm{~m}$ long $\times 3.9 \mathrm{~m}$ wide (to accommodate four $0.96-\mathrm{m}$ planting beds) and was surrounded by a $2-\mathrm{m}$ nontreated buffer. Six soil treatments were assigned to the whole plots: (i) a 50:50 (wt/wt) mixture of methyl bromide and chloropicrin (MBC) (TriCal Inc.) applied at $392 \mathrm{~kg}$ a.i./ha as a positive control; (ii) a $60: 40$ ( vol/vol) mixture of chloropicrin + 1,3-dichloropropene applied at 295 liters a.i./ha (Pic-Clor 60, Soil Chemicals Corp.); (iii) metam-sodium applied at $358 \mathrm{~kg}$ a.i./ha (Vapam HL, Amvac Chemical Corp.); (iv) 6 weeks of solarization using 0.05 -mm-thick transparent high-density polyethylene film (Berry Plastics Corp.); (v) a nontreated negative control; and (vi) endomycorrhizae (AM120, Glomus spp., Reforestation Technologies International) applied at a rate of $8.9 \mathrm{~kg} / \mathrm{ha}$ in seed furrows at planting. In experiment 1 , AM120 was also applied to MBC, Pic-Clor 60, and metam-sodium plots to replenish mycorrhizae lost during chemigation $(2,30)$. In experiment 2 , the AM120 treatment was omitted but AM120 was applied to MBC, Pic-Clor 60, metam-sodium, and solarization treated plots. AM120 was used to substitute for an abandoned fallow treatment in experiment 1 , so that its effects on plant growth could be observed without chemigants. AM120 was not expected to control F. oxysporum f. sp. vasinfectum.

Plots were cultivated to remove planting beds and to smooth the soil surface before soil treatments were applied. MBC and Pic-Clor
60 treatments were shank-injected by a commercial applicator (TriCal) on 27 July 2007 (experiment 1), and on 30 June 2008 (experiment 2). Both treatments were covered and sealed around the plot edges by 0.025 -mm-thick transparent high-density polyethylene film for 3 weeks following application. Plots designated for metam-sodium or solarization were irrigated using drip tape with emitters on a $30-\mathrm{cm}$ spacing (T-Systems International; Eurodrip). The drip lines were placed $51 \mathrm{~cm}$ apart on the soil surface. Metam-sodium plots were preirrigated with $2.5 \mathrm{~cm}$ of water. Six or seven days following preirrigation, Vapam HL diluted in water was applied through the drip lines so that each plot received approximately 1,500 liters of the diluted chemical during a 6.5 -h period. Metam-sodium applications were made on 8 August 2007 (experiment 1) and 17 July 2008 (experiment 2). Solarization plots with drip lines in place were covered with polyethylene film which was buried to a depth of $15 \mathrm{~cm}$ or more around the plot perimeter. Each solarization plot received $3.8 \mathrm{~cm}$ of water on the first day of solarization (1 August 2007, experiment 1; 22 July 2008, experiment 2). The polyethylene film was kept in place for 6 weeks. Temperature was monitored in one solarization plot in each experiment using a HOBO sensor (S-TMB-M002, Onset Computer) at a depth of $10 \mathrm{~cm}$ in experiment 1 and $15 \mathrm{~cm}$ in experiment 2 .

Cultivar treatments. After all soil treatment applications were completed, plots were tilled to form four planting beds on a $0.96-\mathrm{m}$ spacing and oriented along the length of each plot. Treatment evaluations were conducted in the middle two beds of each plot. A 12.24-m section of bed, centered in the length of each of the middle beds, was divided into four 2.6-m row sections, each separated by $0.61 \mathrm{~m}$ of nonplanted bed. This arrangement provided a space of $1.5 \mathrm{~m}$ separating the evaluation area from the plot perimeter, and resulted in four 2.6-m row sections in each half of each whole plot. Four cultivars varying in resistance to race 4 were randomly assigned to the row sections in each half of each whole plot. The cultivars included a highly resistant Pima (Phytogen 800), a highly susceptible Pima (DP 744), and two moderately susceptible Upland cultivars (DP 444 and Phytogen 72) (34).

Plant evaluations. Treatment evaluations based on plant characteristics were conducted in the fall, after treatment applications were completed, and in the spring following a winter fallow period. In California, cotton is normally planted around early April and harvest begins in late September. In experiment 1, plots were planted on 27 September 2007 and on 6 May 2008; in experiment 2, plots were planted on 29 September 2008 and on 1 May 2009. At each planting, 52 seeds were hand-planted at 5-cm intervals within each 2.6-m row section.

Plant response to race 4 of $F$. oxysporum f. sp. vasinfectum was evaluated based on four measurements: mortality (the proportion of plants that were dead, both fall and spring evaluations), and plant height, number of mainstem nodes, and vascular discoloration (spring evaluations only). To evaluate plant mortality, the total number of plants and the number of dead plants were counted, beginning shortly after plant emergence (1 to 2 weeks after planting). Because plots were prepared using standard tillage practices, only plants within a $1.5-\mathrm{m}$ section of each $2.6-\mathrm{m}$ row section were sampled to minimize the effects of soil movement between adjoining row sections with different cultivars. In experiment 1 , mortality data were recorded twice in the fall evaluation (26 October and 23 November 2007) and four times in the spring evaluation (20 May, 9 and 24 June, 1 August). Because it proved difficult to positively identify seedlings that died if the duration between inspections was too long, counts of live and dead plants were recorded weekly in experiment 2 . The small weekly changes in plant mortality were then accumulated within sequential 3-week periods, yielding four equally spaced mortality estimates. Weekly assessments of plant mortality in experiment 2 were made from 9 October to 20 November 2008, and 15 May to 31 July 2009. At each assessment, dead plants were uprooted and removed to minimize inoculum production. Therefore, each sequential estimate of plant mortality represented the mortality that occurred within the sampling interval. Accumulated mortality, the total num- 
ber of dead plants from all assessment dates, was also estimated in each experiment.

Plant height (measured from the soil surface to the mainstem terminal) and number of nodes (beginning with the cotyledon as node 1 and counting to the uppermost leaf $>2.5 \mathrm{~cm}$ in diameter) were recorded on two dates (experiment 1, 6 June and 1 August 2008; experiment 2, 26 June and 31 July 2009) from five randomly selected plants in each 2.6-m row section. The same plants were examined during sequential observations, so dead plants were regarded as missing data for analyses of height, number of nodes, and vascular discoloration. Vascular discoloration of both the lower stem and upper taproot was evaluated in conjunction with the second set of plant measurements. Separate ratings for stem and root were recorded because discoloration between the two plant parts did not always appear congruent. To assess vascular discoloration, each plant was uprooted and stem and root were separated by cutting the plant at the former soil level. Stems and roots were cut again $15 \mathrm{~cm}$ above (stem) or below (root) the previous cut. After the cut surface of the stem or root was examined at the end farthest from the soil surface, each section was also sliced longitudinally. Discoloration of the cross- and longitudinal sections were rated according to the following scale: $0=$ no symptoms, $1=$ one to two light-brown spots or streaks of vascular discoloration, $2=$ more than two light-brown spots or streaks, or one to two mediumbrown spots or streaks of vascular discoloration, $3=$ prominent dark-brown vascular discoloration confined to xylem, or mediumbrown discoloration spread beyond xylem, 4 = dark-brown discoloration spread well beyond xylem to encompass most of the exposed tissue, and $5=$ plant death at time of assessment.

Soil counts of $\boldsymbol{F}$. oxysporum. The influences of soil treatments on inoculum levels of $F$. oxysporum in the soil were also assessed. F. oxysporum populations were estimated from soil samples taken immediately before soil treatment application, and again immediately before cotton was planted in the fall. At each assessment, soil cores $(1.9 \mathrm{~cm}$ diameter $\times 20.3 \mathrm{~cm}$ long) were taken from near the center of each whole plot. Three cores were collected from each plot in experiment 1, and five cores were collected from each plot in experiment 2. Cores from each sampling of a given plot were combined, thoroughly mixed, air-dried for 3 weeks in the laboratory, and ground to a uniform texture (75 to 100 mesh) using a Quaker City grinding mill (model 4-E, Straub Co.). Combined samples were stored at $6^{\circ} \mathrm{C}$ until $F$. oxysporum were quantified. The storage period ranged from 14 to 19 months for experiment 1 , and from 5 to 13 months for experiment 2. One gram of ground soil removed from each combined sample was mixed thoroughly in $9 \mathrm{ml}$ of $0.1 \%$ sterile water agar. Three volumes $(400,600$, and 800 $\mu \mathrm{l})$ of the resulting soil suspension were each spread on five plates of Komada's medium (25) to determine the most appropriate volume for visualizing colonies of fusaria. Plates were incubated at room temperature with a 12 -h photoperiod provided by fluorescent lights, and colonies of all $F$. oxysporum were counted after 7 to 9 days. Ten additional plates of Komada's medium were spread with a freshly made soil suspension using the most appropriate volume as indicated by the initial counts. Colony counts from all 15 plates corresponding to the most appropriate dilution for each sample (five initial plates and 10 additional plates) were used to estimate colony-forming units per gram of soil (air-dried to constant weight).

Data analyses. Data from the two experiments were analyzed separately by mixed-model ANOVA using PROC GLIMMIX of SAS (SAS, ver. 9.2, SAS Institute). Initial analyses of plant mortality, plant height, and number of nodes from both experiments resulted in highly significant three-way interactions that were difficult to interpret. Those analyses were further partitioned by cultivar (plant mortality by time) or sampling date (plant height, number of nodes) to facilitate interpretation.

In the analyses of accumulated plant mortality, the response variable was the proportion of plants that died over the entire duration of each experiment and the fixed effect was soil treatment. The proportions of dead plants were transformed using a modification of the Freeman and Tukey (11) transformation recommended by Zar (37) to avoid problems with heterogeneity of variance. Block and the block*treatment interaction were included as random effects, with the latter term serving as the error term for testing the effect of treatment. In analyses of plant mortality by time, the response variable was the proportion of plants that were dead. Fixed effects were date of sampling, soil treatment, and their interaction. The proportions of dead plants were transformed as for analyses of accumulated plant mortality. Block was a random effect. Also, the block*treatment and block*treatment*date interactions were included as random effects to serve as error terms for testing effects of treatment and date, respectively. Untransformed means are presented.

Respective analyses of plant height and number of nodes included fixed effects of soil treatment, cultivar, and their interaction. Block was included as a random effect. In addition, random effects of block*treatment and block*treatment*cultivar were included as error terms, respectively, for fixed effects of soil treatment and cultivar.

Because the vascular discoloration ratings are ordinal, mean ratings corresponding to each $2.6-\mathrm{m}$ row section were analyzed. Examination of residual and normal quantile-quantile plots indicated the assumptions of normality and homogeneity of variance were satisfied. Fixed effects included soil treatment, cultivar, and their interaction. Random effects included block, and block*treatment and block*treatment*cultivar interactions. The latter two terms were included as error terms for fixed effects of soil treatment and cultivar, respectively.

In analyses of $F$. oxysporum populations in soil, the response variable was the number of colony-forming units per plate. Counts from the individual plates $(n=15)$ were treated as subsamples. Fixed effects included soil treatment, time (pre- or post-treatment), and their interaction. Block was treated as a random effect, and the block*treatment interaction was included as an error term for testing the fixed effects. Because residual plots of initial analyses indicated heterogeneous variances, counts of CFUs were square roottransformed. Untransformed means are presented.

In all analyses, denominator degrees of freedom were adjusted using the Kenward-Rogers correction. When date*treatment or cultivar*treatment interactions were significant, simple effects were examined using the SLICE option of the LSMEANS statement. Mean comparisons were adjusted for multiplicity controlling the experiment-wise type-I error rate at $\alpha=0.05$ using the ADJUST=SIMULATE option.

\section{Results}

The HOBO sensor in the monitored solarization plot indicated that soil temperatures at a $10-\mathrm{cm}$ depth in the first experiment ranged from 33 to $49.7^{\circ} \mathrm{C}$, with a daily average of approximately $40^{\circ} \mathrm{C}$, over 6 weeks. In the second experiment, soil temperatures at a $15-\mathrm{cm}$ depth ranged from 36.5 to $47.7^{\circ} \mathrm{C}$, with a daily average of approximately $41^{\circ} \mathrm{C}$.

Accumulated plant mortality. Because of the similarity of results between fall and spring assessments of plant mortality, only the results of the spring assessments are reported. Plant emergence for each combination of cultivar and soil treatment in experiment 1 ranged from 20 to 28.6 plants per $1.5 \mathrm{~m}$, with a mean \pm SE of 26.4 \pm 0.4 . Analysis of accumulated plant mortality indicated significant effects of cultivar $(F=67.00 ; \mathrm{df}=3,53.22 ; P<0.01)$ and soil treatment $(F=40.94 ; \mathrm{df}=5,14.33 ; P<0.01)$, as well as a significant cultivar*treatment interaction $(F=4.72$; df $=15,52.41 ; P<$ $0.01)$. When the interaction was sliced by cultivar, significant differences were observed among treatments in all cultivars. In the case of cultivars Phytogen 800 and 72, accumulated mortality was highest for the control and AM120 treatments, intermediate for the Pic-Clor 60 and metam-sodium treatments, and lowest for the MBC and solarization treatments (Fig. 1, 1A, 1C). For DP 744, accumulated mortality for the MBC, Pic-Clor 60, and solarization treatments was significantly lower than for the control, AM120, and metam-sodium treatments. Of the most effective treatments for 
DP 744 in experiment 1, only MBC had lower mortality than PicClor 60 (Fig. 1, 1B). For DP 444, accumulated mortality was higher in the control and AM120 treatments than for MBC, PicClor 60, and solarization, but only the MBC treatment had less mortality than the metam-sodium treatment (Fig. 1, 1D).

In experiment 2, plant emergence for each cultivar and soil treatment combination ranged from 24.7 to 28.7 plants per $1.5-\mathrm{m}$ section, with a mean $\pm \mathrm{SE}$ of $27.1 \pm 0.2$. Significant differences in accumulated mortality were observed among cultivars $(F=52.79 ; \mathrm{df}$ $=3,45.48 ; P<0.01)$ and soil treatments $(F=18.11 ; \mathrm{df}=4,11.49 ; P$ $<0.01)$, and the cultivar*treatment interaction was not significant $(F$ $=1.75 ; \mathrm{df}=12,44.85 ; P=0.09)$. Accumulated mortality for all cultivars was generally higher in the nontreated control than in the MBC, Pic-Clor 60, and solarization treatments. Accumulated mortality in the metam-sodium treatment was intermediate between the nontreated control and the most effective treatments.

Plant mortality, experiment 1. Analyses of plant mortality indicated significant effects of date and soil treatment for each cultivar, but in each case the date*treatment interaction was also significant (Supplementary Table 1). When the interaction for Phytogen 800 was sliced by date, significant differences among the soil treatments were indicated only for the mortality assessment at 2 and 5 weeks after planting (Fig. 2, 1A, lowercase). At the week 2 assessment, plant mortality was highest in the nontreated control and lowest in the MBC and solarization treatments. By week 5, the highest mortality was observed in the nontreated control and AM120 treatments. When the date*treatment interaction was sliced by treatment, mortality assessments at the different dates were statistically similar only for the MBC treatment (Fig. 2, 1A, uppercase). Observed plant mortality in the other treatments differed among sample dates, and in each case the highest mortality was observed at 5 weeks after planting.

In the case of DP 744, slices by date of the date* soil treatment interaction indicated significant differences among soil treatments at all sample times (Fig. 2, 1B). Mortality was generally highest in the nontreated and AM120 treatments, and lowest in the MBC, PicClor 60, and solarization treatments. Mortality in the metam-so- dium treatment was either similar to that in the control (weeks 2, 5, 12) or intermediate between the nontreated control and the more effective treatments (week 7; Fig. 2, 1B). When the interaction was sliced by soil treatment, no differences in mortality were observed among sample times for the MBC and solarization treatments. For other treatments, mortality was highest at the week 5 assessment (Pic-Clor 60, nontreated, metam-sodium), or at both weeks 5 and 7 (AM120). Mortality was generally lowest at the first (week 2) and last (week 12) sample times (Fig. 2, 1B).

Slices by date of the date*treatment interaction for Phytogen 72 indicated significant differences among soil treatments at all but the last sampling (Fig. 2, 1C). On dates where differences occurred, plant mortality was generally highest in the control treatment (weeks 2 and 5) or in the control and AM120 treatments (week 7), and lowest in the MBC, Pic-Clor 60, and solarization treatments (Fig. 2, 1C). Mortality in the metam-sodium treatment was generally lower than in the control, but higher than in the more effective treatments. When the interaction was sliced by treatment, no differences were observed in mortality estimates at the different sampling times for the MBC or solarization treatments. Significant differences among dates of assessment were indicated for the remaining soil treatments (Fig. 2, 1C). Estimated plant mortality was higher at the week 5 assessment than at other samplings for the Pic-Clor 60 and metam-sodium treatments. Mortality was also highest at week 5 for the control and AM120 treatments, and in these treatments the lowest mortality was observed at week 2 (control) or weeks 2 and 12 (AM120).

When the date*soil treatment interaction was sliced by date for DP 444, differences among treatments were indicated for plant mortality assessments only at weeks 2 and 5 (Fig. 2, 1D). For the week 2 assessment, only the MBC and Pic-Clor 60 treatments exhibited plant mortality that was lower than in the nontreated control (Fig. 2, 1D). By week 5 after planting, plant mortality was highest in the metam-sodium, control, and AM120 treatments, and lowest in the MBC, Pic-Clor 60, and solarization treatments (Fig. $2,1 D)$. When the interaction was sliced by treatment, no differences were observed among mortality estimates on different sam-

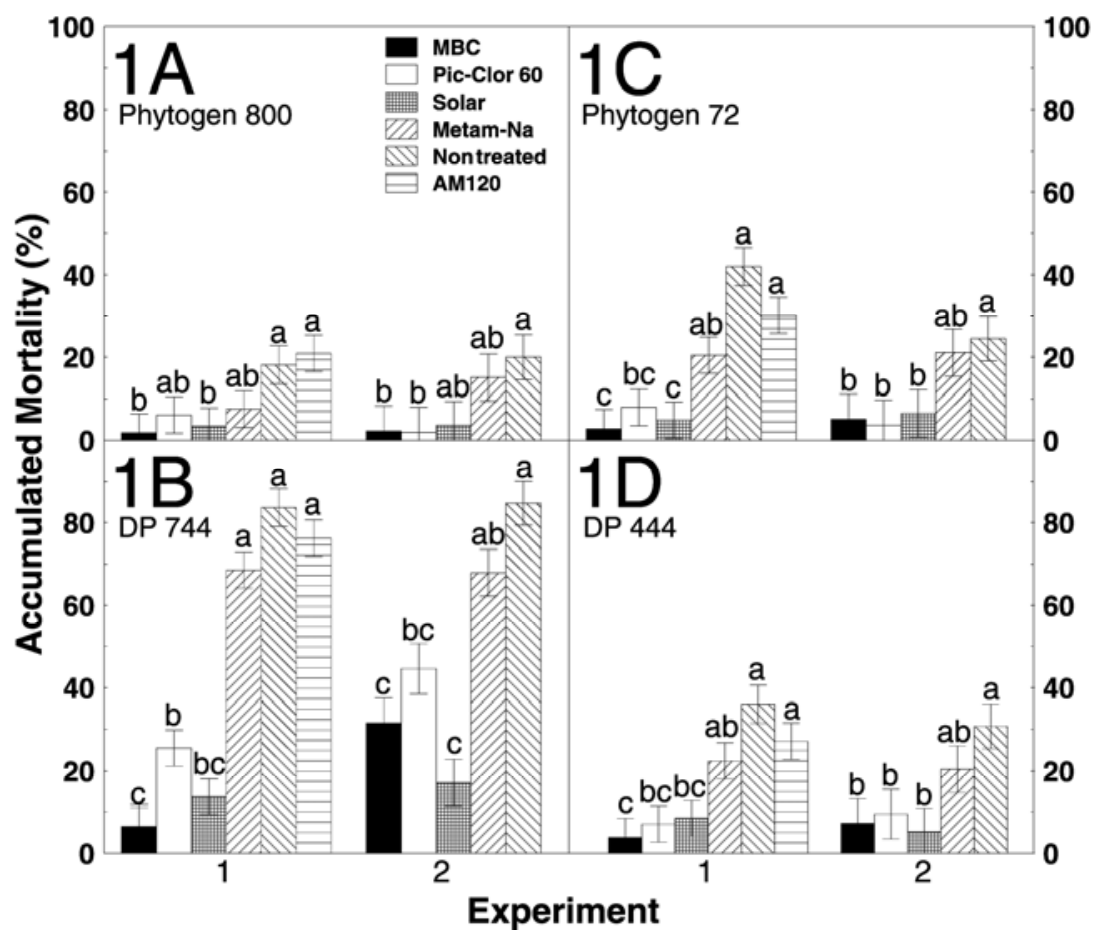

Fig. 1. Mean percentage of accumulated (total) plant mortality $( \pm S E)$ in experiments 1 and 2. Accumulated mortality of cotton cultivars Phytogen $800(1 \mathrm{~A})$, DP $744(1 \mathrm{~B})$, Phytogen 72 (1C), and DP 444 (1D) was evaluated for six soil treatments (MBC, 50:50 methyl-bromide + chloropicrin; Pic-Clor 60, 60:40 chloropicrin + 1,3-dichloropropene; Solar, solarization; Metam-Na, metam-sodium; non-treated control; AM120, commercial mycorrhizae preparation). Mean ( \pm SE) initial plant population per plot for each combination of cultivar and soil treatment was $26.4 \pm 0.4$ in experiment 1 and $27.1 \pm 0.2$ in experiment 2 . Means with the same lowercase letter among treatments within experiment and cultivar are not significantly different $(\alpha=0.05)$. 
ple dates for MBC, Pic-Clor 60, or solarization treatments. Plant mortality corresponding to the other treatments was highest at the second assessment (week 5; Fig. 2, 1D).

Plant mortality, experiment 2. Sample date and soil treatment had significant effects on plant mortality of all cultivars in experiment 2 , but corresponding date*treatment interactions were significant for all cultivars except DP 744. For Phytogen 800, slices of the interaction by date indicated differences among soil treatments by week 4 after planting, but not for assessments at 7,10, or 13 weeks after planting (Fig. 2, 2A). At the week 4 assessment, plant mortality was highest in the nontreated and metam-sodium treatments and least in the MBC, Pic-Clor 60, and solarization treatments. When the date* treatment interaction was sliced by treatment, estimates of mortality at the different dates were similar for MBC, PicClor 60, and solarization (Fig. 2, 2A). Observed mortality in the nontreated control and metam-sodium treatments differed among assessment dates, and the highest mortality for both treatments was observed at the week 4 assessment.

For DP 744, which did not exhibit a significant date*soil treatment interaction, plants in the nontreated control and metam-sodium treatments exhibited higher mortality than in the MBC, PicClor 60, and solarization treatments. The pattern of plant mortality over sampling dates indicated mortality was generally highest in the first evaluation period (week 4 after planting) and lowest at the last sampling (week 13).

In the case of Phytogen 72, slices of the interaction by date indicated significant differences among treatments only at week 4 . By week 4 after planting, mortality was highest for the nontreated control and metam-sodium treatments and lowest for the MBC, Pic-Clor 60, and solarization treatments. When the interaction was sliced by soil treatment, plant mortality was not different among sampling times for MBC, Pic-Clor 60, or solarization treatments,

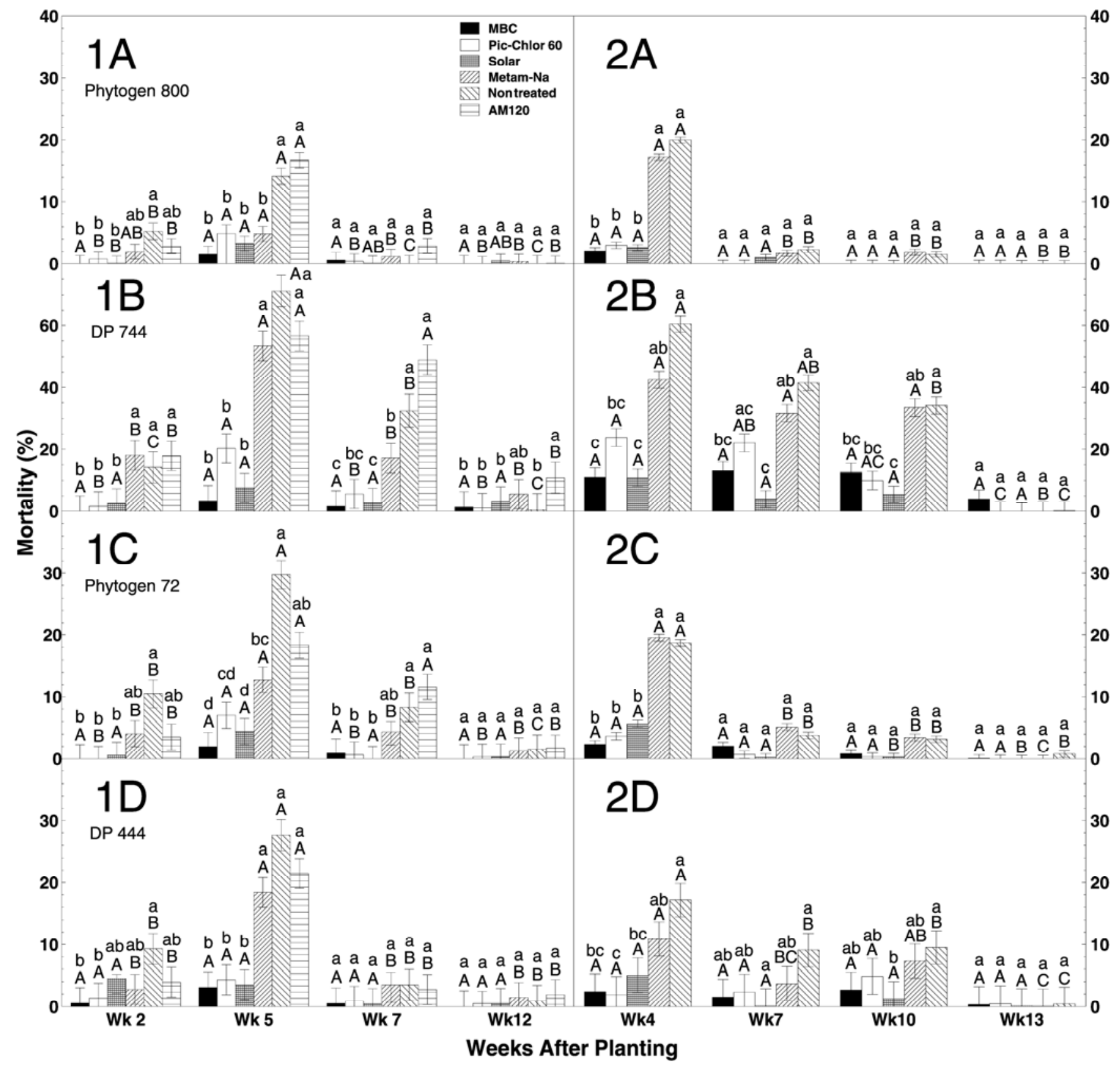

Fig. 2. Mean percentage of plant mortality $( \pm S E)$ by time in experiment $1(1 \mathrm{~A}-1 \mathrm{D})$ and experiment $2(2 \mathrm{~A}-2 \mathrm{D})$. Mortality of cotton cultivars Phytogen $800(1 \mathrm{~A}, 2 \mathrm{~A})$, $\mathrm{DP} 744$ $(1 \mathrm{~B}, 2 \mathrm{~B})$, Phytogen $72(1 \mathrm{C}, 2 \mathrm{C})$, and DP $444(1 \mathrm{D}, 2 \mathrm{D})$ were evaluated for six soil treatments (MBC, 50:50 methyl-bromide + chloropicrin; Pic-Clor 60, 60:40 chloropicrin + 1,3dichloropropene; Solar, solarization; Metam-Na, metam-sodium; non-treated control; AM120, commercial mycorrhizae preparation). Scale of plant mortality values (y-axis) is different for the more susceptible cultivar DP 744. Uppercase letters indicate differences among sampling periods within treatments. Lowercase letters indicate differences among treatments within sampling periods $(\alpha=0.05)$. 
but mortality was highest at week 4 after planting for the nontreated and metam-sodium treatments (Fig. 2, 2C).

When the date*soil treatment interaction was sliced by date for cultivar DP 444, significant differences in plant mortality were observed among treatments for assessments by weeks 4,7 , and 10 , but not at week 13 after planting (Fig. 2, 2D). By the week 4 evaluation, mortality of DP 444 was highest in the nontreated control and lowest in the Pic-Clor 60 treatment. By 7 and 10 weeks after planting, mortality was highest in the control and lowest in the solarization treatment. When the date*soil interaction was sliced by treatment, temporal differences in mortality were found only in the nontreated and metam-sodium treatments. In those treatments, mortality generally declined from a maximum during the first evaluation period (week 4) to a low level during the last period (week 13; Fig. 2, 2D).

Plant height. In experiment 1 , plant height was measured for 1,073 plants on 24 June and 1,003 plants on 1 August 2008. In experiment 2, plant height was measured for 1,095 plants on 26 June and 1,085 plants on 31 July 2009. Analyses of plant height indicated a significant cultivar*soil treatment interaction for each sample date in both experiments 1 and 2 (Table 1), so the main effects of soil treatment and cultivar were conditional on levels of the other factor. In experiment 1 , overall trends in plant height appeared similar between the two evaluation dates (24 June and 1 August 2008; Fig. 3, 1A, 1B). For both sample dates, slices by cultivar of the cultivar*treatment interaction indicated significant differences among soil treatments. In both analyses, plants were generally tallest in the MBC and Pic-Clor 60 treatments irrespective of cultivar. Plants in the solarization, AM120, nontreated, and metam-sodium treatments were similar in height, but smaller than those in the MBC and Pic-Clor 60 treatments.

At the first evaluation of plant height in experiment 2 (26 June, Fig. 3, 2A), slices by cultivar of the cultivar*soil treatment interaction indicated significant treatment effects for all cultivars. For

Table 1. Effect of soil treatments and cotton cultivar on plant height, number of mainstem nodes, and root discoloration

\begin{tabular}{|c|c|c|c|c|c|c|c|c|c|c|c|c|c|}
\hline \multirow[b]{2}{*}{ Date } & \multirow[b]{2}{*}{ Model effect } & \multicolumn{3}{|c|}{ Height $^{\mathrm{a}}$} & \multicolumn{3}{|c|}{ Nodes $^{\mathbf{a}}$} & \multicolumn{3}{|c|}{ Root discoloration $^{a}$} & \multicolumn{3}{|c|}{ Stem discoloration $^{a}$} \\
\hline & & $F$ & df & $P$ & $F$ & df & $P$ & $F$ & df & $P$ & $F$ & df & $P$ \\
\hline \multicolumn{14}{|l|}{ Experiment 1} \\
\hline 24 June & Cultivar & 31.60 & $3,46.87$ & $<0.01$ & 25.21 & $3,48.28$ & $<0.01$ & - & - & - & - & - & - \\
\hline 2008 & Soil trtmt & 317.25 & $5,13.52$ & $<0.01$ & 59.07 & $5,17.83$ & $<0.01$ & - & - & - & - & - & - \\
\hline$\left(\right.$ Week 7) ${ }^{b}$ & $\mathrm{Cv} * \operatorname{trtmt}$ & 3.87 & $15,44.89$ & $<0.01$ & 2.29 & $15,47.10$ & 0.02 & - & - & - & - & - & - \\
\hline 1 August & Cultivar & 68.46 & $3,52.49$ & $<0.01$ & 5.26 & $3,46.48$ & $<0.01$ & 31.51 & $3,57.32$ & $<0.01$ & 32.39 & $3,60.80$ & $<0.01$ \\
\hline 2008 & Soil trtmt & 26.21 & $5,16.32$ & $<0.01$ & 1.97 & $5,15.14$ & 0.14 & 22.54 & $5,14.67$ & $<0.01$ & 20.34 & $5,14.97$ & $<0.01$ \\
\hline (Week 12) & $\mathrm{Cv} * \operatorname{trtmt}$ & 2.97 & $15,50.42$ & $<0.01$ & 2.11 & $15,42.71$ & 0.03 & 2.82 & $15,55.00$ & $<0.01$ & 3.45 & $15,57.74$ & $<0.01$ \\
\hline \multicolumn{14}{|c|}{ Experiment 2} \\
\hline 26 June & Cultivar & 45.02 & $3,42.55$ & $<0.01$ & 5.48 & $3,43.02$ & $<0.01$ & - & - & - & - & - & - \\
\hline 2009 & Soil trtmt & 32.77 & $4,12.19$ & $<0.01$ & 9.83 & $4,11.61$ & $<0.01$ & - & - & - & - & - & - \\
\hline (Week 8) & $\mathrm{Cv} * \operatorname{trtmt}$ & 4.33 & $12,42.21$ & $<0.01$ & 2.64 & $12,42.34$ & 0.01 & - & - & - & - & - & - \\
\hline 31 July & Cultivar & 23.23 & $3,36.61$ & $<0.01$ & 24.48 & $3,35.63$ & $<0.01$ & 37.26 & $3,191.90$ & $<0.01$ & 33.52 & 3, 192.1 & $<0.01$ \\
\hline 2009 & Soil trtmt & 1.02 & $4,14.62$ & 0.43 & 3.04 & $4,14.41$ & $>0.05$ & 8.39 & $4, \quad 11.22$ & $<0.01$ & 7.21 & $4,11.26$ & $<0.01$ \\
\hline (Week 13) & $\mathrm{Cv}^{*}$ trtmt & 2.84 & $12,36.26$ & $<0.01$ & 1.71 & $12,34.99$ & 0.11 & 3.55 & $12,191.90$ & $<0.01$ & 3.69 & $12,192.1$ & $<0.01$ \\
\hline
\end{tabular}

${ }^{\text {a }} F$ test of fixed effects; $\mathrm{df}=$ degrees of freedom (numerator, denominator); $P$ value.

$\mathrm{b}$ Weeks after planting.

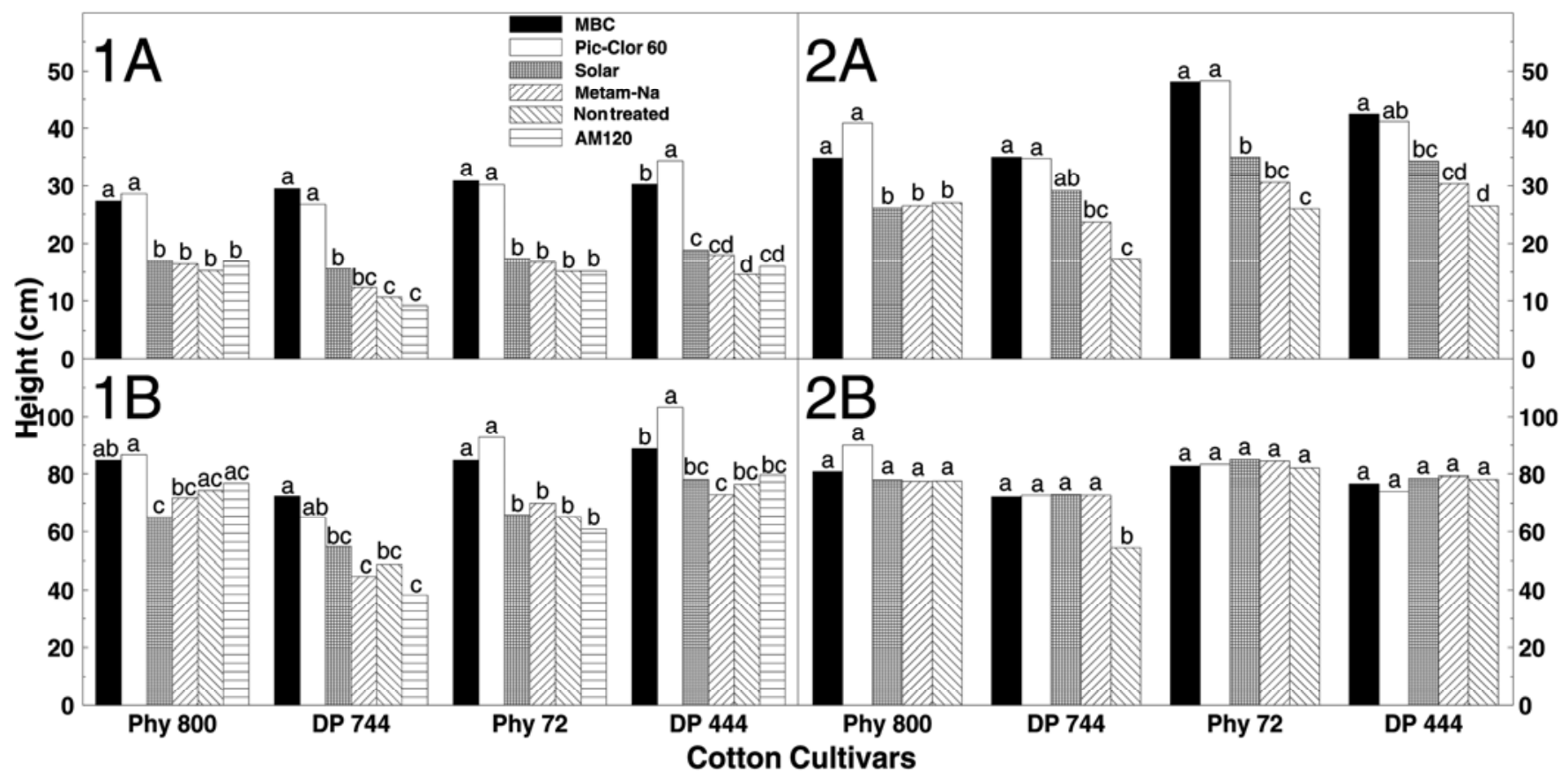

Fig. 3. Mean plant height of cotton cultivars Phytogen 800, DP 744, Phytogen 72, and DP 444 for soil treatments 50:50 methyl-bromide + chloropicrin (MBC), $60: 40$ chloropicrin + 1,3-dichloropropene (PicClor 60), solarization (Solar), metam-sodium (Metam-Na), nontreated control, and a commercial mycorrhizae product (AM120). Plant height was measured on 24 June ( $1 \mathrm{~A} ; 7$ weeks after planting) and 1 August 2008 (1B; 12 weeks after planting) in experiment 1, and on 26 June (2A; 8 weeks after planting) and 31 July 2009 (2B, 13 weeks after planting) in experiment 2 . SE: $1 \mathrm{~A}( \pm 1.0$ to 1.3$), 1 \mathrm{~B}( \pm 4.0$ to 4.5$), 2 \mathrm{~A}( \pm 1.8$ to 2.0$)$, and $2 \mathrm{~B}( \pm 3.5$ to 3.8$)$. Means with the same lowercase letter among treatments within cultivar and experiment are not significantly different $(\alpha=0.05)$. 
Phytogen 800 and 72, plant height was greater in the $\mathrm{MBC}$ and Pic-Clor 60 treatments than in other treatments. For DP 744, height of plants in MBC, Pic-Clor 60, and solarization treatments was greater than in the nontreated control, but plant height in the solarization treatment was not different from that in the metam-sodium treatment. For the cultivar DP 444, plant height tended to decrease in the soil treatment order of MBC, Pic-Clor 60, solarization, metam-sodium, and nontreated. In the 31 July evaluation of plant height, the soil treatment*cultivar interaction sliced by cultivar indicated significant differences in plant height among soil treatments only for DP 744. Plants of this cultivar in the nontreated control were significantly smaller than plants in other treatments.

Number of mainstem nodes. Sample sizes for estimates of the number of mainstem nodes were the same as plant height. Analyses of the number of mainstem nodes in experiment 1 indicated the cultivar*soil treatment interaction was significant on both assessment dates (24 June and 1 August 2008; Table 1). Slices of this interaction by cultivar for the first evaluation date indicated plants in the MBC and Pic-Clor 60 treatments possessed more mainstem nodes than plants of other treatments for all cultivars (Supplementary Fig. 1). When the cultivar*soil treatment interaction was sliced by cultivar for the 1 August sampling of experiment 1, differences were found among soil treatments for only DP 444, where plants in the Pic-Clor 60 treatment had more nodes than those in the AM120 and metam-sodium treatments.

Analysis of plant node numbers in experiment 2 revealed a significant cultivar*soil treatment interaction only for the first assessment (26 June 2009, Table 1). Slices of the interaction by cultivar for the 26 June evaluation indicated significant differences among soil treatments for each cultivar. Plants in the Pic-Clor 60 treatment had more nodes than those in the nontreated, solarization, or metam-sodium treatments for Phytogen 800, DP 744, and Phytogen 72. Also, mean number of nodes in the Pic-Clor 60 plots was higher than in the nontreated plots of DP 444. Plants in the MBC treatment had more nodes than those in the nontreated plots for DP 744, Phytogen 72, and DP 444, and in the metam-sodium treatment for Phytogen 72. Mean numbers of nodes differed between solarization and nontreated plots only for DP 744 .
Vascular discoloration. Vascular discoloration ratings were taken from a total of 987 plants in experiment 1 and 1,084 plants in experiment 2. Patterns of vascular discoloration ratings among combinations of soil treatments and cultivars appeared generally consistent between experiments whether the ratings were obtained from the upper root or lower stem, although ratings tended to be higher in the upper root (Fig. 4). For both root and stem ratings in both experiments, analyses indicated significant interactions between soil treatment and cultivar (Table 1). In experiment 1, when the interaction for the upper root or lower stem was sliced by cultivar, significant differences in discoloration rating were found among treatments for all cultivars except for the lower stem ratings of Phytogen 800 (Fig. 4, 1A, 1B). For the upper root of Phytogen 800 , discoloration ratings for the Pic-Clor 60, solarization, and metam-sodium treatments were significantly lower than for the nontreated control (Fig. 4, 1A). Ratings of the upper roots of Phytogen 800 in the MBC and AM120 treatments were intermediate to those of other treatments, although MBC was significantly different from the nontreated control before adjusting for multiple comparisons $(P=0.001)$. For DP 744 (upper root and lower stem), discoloration ratings for the AM120, nontreated, metam-sodium, and Pic-Clor 60 treatments were higher than for the MBC and solarization treatments (Fig. 4, 1A, 1B). Roots and stems of Phytogen 72 exhibited the highest discoloration ratings for the nontreated control, while the lowest ratings were found for the MBC, Pic-Clor 60, and solarization treatments (Fig. 4, 1A, 1B). For Phytogen 72, discoloration ratings for the metam-sodium and AM120 treatments tended to be intermediate to those of other treatments, although they were not different from those of the MBC, Pic-Clor 60, metam-sodium, or the nontreated control (AM120) treatments. Upper root discoloration for DP 444 in the solarization treatment was lower than in the metam-sodium, nontreated, and AM120 treatments, but not different than the MBC and Pic-Clor 60 treatments (Fig. 4, 1A). Lower stem ratings for DP 444 in the AM120 treatment were higher than for plants in the PicClor 60 and solarization treatments, but not for other treatments. When the cultivar*soil treatment interaction was sliced by soil treatment, plants of Phytogen 800 had upper root and lower stem

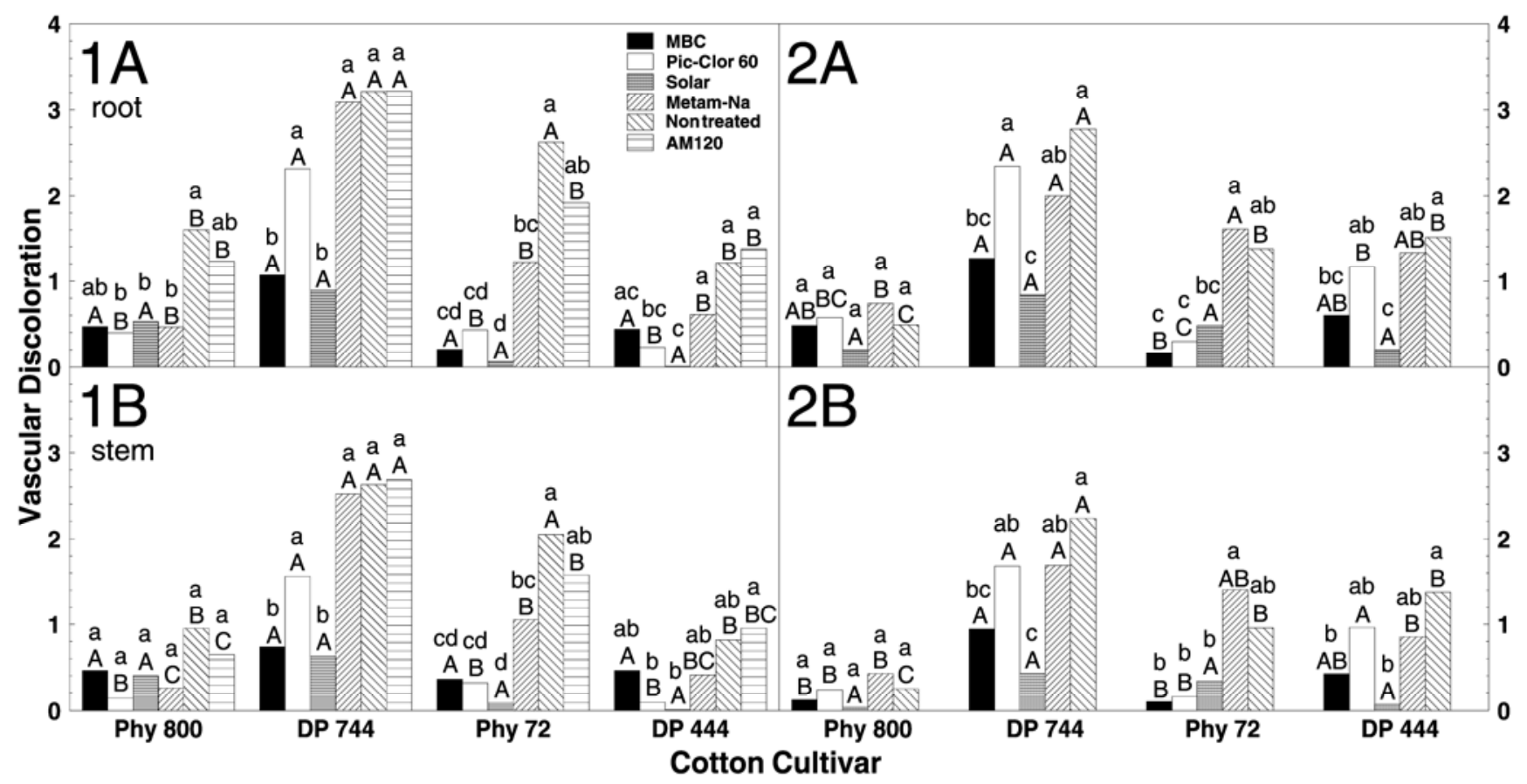

Fig. 4. Mean vascular discoloration of cotton cultivars Phytogen 800, DP 744, Phytogen 72, and DP 444 for six soil treatments (MBC, $50: 50$ methyl-bromide + chloropicrin; Pic-Clor 60, 60:40 chloropicrin + 1,3-dichloropropene; Solar, solarization; Metam-Na, metam-sodium; non-treated control; AM120, commercial mycorrhizae preparation). Discoloration was rated in a longitudinal cross-section of the upper root, $15 \mathrm{~cm}$ below soil level $(1 \mathrm{~A}, 2 \mathrm{~A})$, and lower stem, $15 \mathrm{~cm}$ above soil level (1B, 2B). Data from experiments $1(1 \mathrm{~A}, 1 \mathrm{~B})$ and $2(2 \mathrm{~A}, 2 \mathrm{~B})$ are presented. SE: $1 \mathrm{~A}( \pm 0.3$ to 0.5$), 1 \mathrm{~B}( \pm 0.2$ to 0.3$), 2 \mathrm{~A}( \pm 0.3)$, and $2 \mathrm{~B}( \pm 0.2$ to 0.3$)$. Uppercase letters indicate differences among cultivars within treatments. Lowercase letters indicate differences among treatments within cultivars $(\alpha=0.05)$. 
discoloration ratings that were lower than for DP 744 for all treatments except MBC and solarization (Fig. 4, 1A). Discoloration ratings of DP 744 were greater than those of Phytogen 72 and DP 444 for treatments of AM120, Pic-Clor 60, and metam-sodium. In the nontreated control, discoloration ratings of Phytogen 72 and DP 744 were greater than for Phytogen 800 or DP 444 (Fig. 4, 1A, 1B).

In experiment 2 , slices by cultivar of the cultivar*soil treatment interaction indicated significant differences in both upper root and lower stem discoloration ratings among treatments within each cultivar except Phytogen 800 (Fig. 4, 2A, 2B). For DP 744 (root and stem) and DP 444 (root), discoloration ratings in the solarization treatment were lower than in the Pic-Clor 60, metam-sodium, and nontreated control (Fig. 4, 2A, 2B). The same pattern was present for the stem ratings for DP 444, but the discoloration ratings for the $\mathrm{MBC}$ and solarization treatments were only lower than for the nontreated control. In the roots and stems of Phytogen 72, the discoloration ratings for the $\mathrm{MBC}$, Pic-Clor 60, and solarization treatments were generally lower than those of the metam-sodium and nontreated treatments (Fig. 4, 2A, 2B). Slices of the interaction by soil treatment indicated significant differences among cultivars within all treatments except solarization (Fig. 4, 2A). Both root and stem discoloration ratings were generally highest for DP 744, although the ratings for DP 744 were often not statistically different from those of DP 444 or Phytogen 72 for metam-sodium. Root and stem discoloration ratings for DP 444 were higher than for Phytogen 72 only in the Pic-Clor 60 treatment.

Soil counts of $\boldsymbol{F}$. oxysporum. Analyses of soil counts of $F$. oxysporum CFUs indicated significant soil treatment*time interactions in both experiments (experiment $1, F=17.67$; $\mathrm{df}=5,17.71$; $P<0.01$; experiment $2, F=39.59$; df $=4,26.05 ; P<0.01$ ), indicating changes in CFUs between sampling times varied among soil treatments. When this interaction was sliced by treatment, Fusarium counts in post-treatment soil samples were significantly reduced in comparison with pretreatment samples only for the MBC, Pic-Clor 60, and solarization soil treatments (Table 2).

\section{Discussion}

In our evaluation of five soil treatments and four cotton cultivars, only the Pic-Clor 60 and solarization treatments were as efficacious as the positive control (MBC) for reducing plant mortality and vascular symptoms caused by race 4 of $F$. oxysporum $\mathrm{f}$. sp. vasinfectum, and in reducing soilborne populations of $F$. oxysporum. These three treatments significantly reduced plant mortality in resistant and highly susceptible cultivars relative to the nontreated control. Our applied rate of metam-sodium was gener- ally not effective at reducing plant mortality, vascular discoloration, or populations of soilborne fusaria, and often did not differ from the nontreated control. Estimates of plant mortality and measurements of plant parameters corresponding to the AM120 mycorrhizal treatment were also similar to those in the nontreated control in most evaluations.

Because the cultivars were planted approximately 4 weeks later than commercial plantings, conditions for plant emergence and early growth were warmer and more favorable than usual (temperature data not shown). Nonetheless, considerable variation was observed among cultivars in their responses to soil treatments. As expected, the most resistant cultivar, Phytogen 800, exhibited the least mortality and vascular discoloration among the cultivars evaluated. The period of highest mortality in all of the cultivars occurred between 3 and 5 weeks after planting (Fig. 2, 1A, 2A), but in Phytogen 800 , this mortality (up to $\sim 20 \%$ ) was generally limited to nontreated and mycorrhizae-treated plots. DP 744, the most susceptible cultivar, exhibited high levels of mortality ( 20 to $71 \%$ ) and vascular discoloration in all treatments except MBC and solarization. In addition, substantial plant mortality in DP 744 continued to accumulate within all but the last evaluation period (weeks 11 to 13). The Upland cultivars Phytogen 72 and DP 444 were intermediate between Phytogen 800 and DP 744 in their plant mortality response to soil treatments. Unlike Phytogen 800, considerable mortality (20 to $30 \%$ ) of the Upland cultivars was observed in the metam-sodium plots, as well as the nontreated and AM120 plots. The period of accumulation of substantial mortality in the Upland cultivars was intermediate compared with those of Phytogen 800 and DP 744.

Measurements of plant height and numbers of mainstem nodes did not discriminate among the soil treatments as clearly as measurements of plant mortality and vascular discoloration. In evaluations up to 7 to 8 weeks after planting, plant height and numbers of nodes often reflected the high efficacy of the MBC and Pic-Clor 60 treatments. However, in later evaluations fewer differences among soil treatments were discernable. This apparent loss of sensitivity may have resulted from the fact that the later comparisons were based on plants that survived Fusarium wilt or escaped infection.

In addition, measurements of plant height and numbers of nodes did not reflect the efficacy of solarization that was indicated by estimates of plant mortality and vascular discoloration. At 7 weeks after planting, all cultivars in the solarization treatment were clearly stunted compared with those in MBC and Pic-Clor 60 plots despite similar levels of plant mortality in the three treatments. Height and numbers of nodes of plants in the solarized plots were most similar to those of surviving plants in the metam-sodium,

Table 2. Effect of soil treatments on populations of Fusarium spp. collected in samples before and after soil treatments ${ }^{\mathrm{a}}$

\begin{tabular}{|c|c|c|c|c|c|}
\hline Treatment $^{\mathrm{b}}$ & $\begin{array}{c}\text { Pretreatment } \\
\text { CFU/g }\end{array}$ & $\begin{array}{c}\text { Post-treatment } \\
\text { CFU } / g^{c}\end{array}$ & $\mathbf{d f}^{\mathbf{d}}$ & $F^{\mathrm{d}}$ & $P^{d}$ \\
\hline \multicolumn{6}{|l|}{ Experiment 1} \\
\hline $\mathrm{MBC}$ & 58.68 & 1.46 & $1,18.2$ & 39.69 & $<0.001$ \\
\hline Pic-Clor 60 & 72.57 & 1.79 & $1,17.5$ & 53.62 & $<0.001$ \\
\hline Solarization & 85.43 & 0.86 & $1,17.5$ & 67.62 & $<0.001$ \\
\hline Metam-sodium & 23.71 & 18.18 & $1,17.5$ & 0.96 & 0.341 \\
\hline Nontreated plots & 15.42 & 26.11 & $1,18.2$ & 1.11 & 0.305 \\
\hline AM120 & 32.37 & 42.03 & $1,17.5$ & 0.33 & 0.573 \\
\hline \multicolumn{6}{|l|}{ Experiment 2} \\
\hline $\mathrm{MBC}$ & 140.14 & 14.76 & $1,27.2$ & 98.65 & $<0.001$ \\
\hline Pic-Clor 60 & 175.87 & 6.96 & $1,27.2$ & 166.10 & $<0.001$ \\
\hline Solarization & 183.99 & 4.99 & $1,25.8$ & 189.20 & $<0.001$ \\
\hline Metam-sodium & 140.92 & 107.27 & $1,25.8$ & 3.54 & 0.071 \\
\hline Nontreated plots & 143.67 & 135.48 & $1,24.5$ & 0.18 & 0.679 \\
\hline
\end{tabular}

${ }^{a}$ Mixed-model ANOVA was used to analyze square-root transformed counts of CFU/g and the SLICE option of the LSMEANS statement in SAS was used to examine the effect of each treatment.

${ }^{\mathrm{b}} \mathrm{MBC}=$ methyl-bromide + chloropicrin; Pic-Clor $60=$ chloropicrin $+1,3$-dichloropropene; AM120 = mycorrhizae (Glomus spp.).

${ }^{\mathrm{c}}$ Pretreatment soil samples were collected immediately before soil treatments were applied. Post-treatment samples were collected immediately before cotton was planted in the fall. SE $= \pm 9.8$ for experiment 1 and \pm 13.9 to 14.2 for experiment 2 .

${ }^{\mathrm{d}} F$ test of fixed effects; $\mathrm{df}=$ degrees of freedom (numerator, denominator); $P$ value. Statistical tests are based on transformed data but untransformed means are presented. 
nontreated, and AM120 plots. This discrepancy among measurements in the solarization treatment became less distinct by the last sampling (week 13) in experiment 1 . In comparison with experiment 1, this effect was diminished by the application of AM120 at planting in experiment 2. Solarization is known to produce an increased growth response in many plants (6), and few cases of plant growth retardation have been documented (18). A previous report of cotton planted into soil solarized for 7 weeks did not report plant stunting in the absence of supplemental mycorrhizae (22). Still, our results suggest that cotton is highly dependent on mycorrhizae, and that solarization reduced the natural populations. Bendavid-Val and colleagues found that applied inoculum of Glomus intraradices remained viable after 8 weeks of solarization, but that indigenous mycorrhizae were effectively eliminated (2). In this study, the addition of AM120 to the solarized plots reduced but did not eliminate plant stunting. Therefore, a higher application rate of AM120 may be necessary in cotton following solarization.

Although vascular discoloration ratings were generally consistent with, but more variable than, estimates of plant mortality, some inconsistencies between the two measurements were noted. For example, the Pic-Clor 60 treatment was consistently among the best treatments based on plant mortality, but was among the least effective treatments for reducing vascular discoloration in DP 744 and 444. Similar to plant height and numbers of nodes, vascular discoloration ratings were obtained from surviving plants or escapees. These ratings might be more consistent with estimates of mortality, and less variable, if vascular discoloration data are obtained earlier in the season when plant survival is higher.

For future experiments, the most appropriate measures for evaluating soil treatments against race 4 appear to be plant mortality and soil counts of $F$. oxysporum. The soil assays did not quantify race 4 of $F$. oxysporum f. sp. vasinfectum directly, but CFU counts of all F. oxysporum were consistent with observed plant mortality. Based on our results, plant mortality should be assessed weekly and accumulated for 3 to 4 weeks after planting. Mortality assessments made during that time period should accurately indicate treatment efficacy. The most appropriate choice of cultivar(s) for future evaluations should be based on the level of sensitivity required. For example, use of a very susceptible cultivar such as DP 744 should enhance the ability to discriminate among soil treatments when levels of soil inocula are low, whereas use of a resistant cultivar such as Phytogen 800 may avoid problems associated with rapid and extensive plant mortality when populations of inocula are high. Based on these results, measurements of plant height and node numbers were less informative and more ambiguous than were estimates of plant mortality. Therefore, collection of these plant measurements is probably not warranted if plant mortality data are available. Also, collection of vascular discoloration ratings corresponding to the upper root and lower mainstem appeared redundant. If vascular discoloration ratings are desired, the labor associated with their collection may be minimized by evaluating only the upper root. Where specific objectives require the documentation of vascular symptoms, plant height, and numbers of nodes, those data should be collected early in the season to reduce variability caused by sampling surviving diseased or healthy plants.

A number of reports have indicated limited efficacy of metamsodium against $F$. oxysporum in soil. McGovern et al. found metam-sodium efficacious against $F$. oxysporum $\mathrm{f}$. sp. radicis-lycopersici only when the chemical was rotavated into the soil after application (27). In a coastal California study, plots treated with $478 \mathrm{~kg}$ a.i/ha metam-sodium applied by drip tape had $41 \%$ fewer colonies of $F$. oxysporum than nontreated plots in one trial, but only $22 \%$ fewer in a second trial (13). Ben-Yephet et al. reported that metam-sodium, applied by sprinkler at a rate of $302.5 \mathrm{~kg}$ a.i./ha, resulted in $22 \%$ fewer propagules of $F$. oxysporum $\mathrm{f}$. sp. vasinfectum than in nontreated plots (3). Our results, applying the maximum labeled rate of $358 \mathrm{~kg}$ a.i./ha by drip tape, were generally consistent with these earlier reports.

Despite the high cost and phase-out of methyl-bromide, formulations containing methyl-bromide are the standard by which other soil treatments are judged (26). Although Pic-Clor 60 and solarization exhibited efficacy equivalent to that of methyl-bromide and chloropicrin, at least for reducing Fusarium wilt of cotton in a heavy clay soil, solarization may be preferable to Pic-Clor 60 . Plants in the Pic-Clor 60-treated plots generally exhibited low mortality (Fig. 1) and excellent growth (Figs. 2 and 3). Soil counts of $F$. oxysporum were also significantly reduced following Pic-Clor 60 application (Table 2). However, vascular discoloration of the highly susceptible cultivar DP 744 in the Pic-Clor 60 plots was comparable to that of plants in nontreated plots, and mortality of DP 744 in the Pic-Clor 60 plots was substantial (>20\%) in experiment 2. The reason for these apparent discrepancies is unclear. One possible explanation is that Pic-Clor 60 was not as effective at reducing propagules of race 4 as $\mathrm{MBC}$ and solarization, and that differences in the populations of $F$. oxysporum between Pic-Clor 60 and these two treatments may not be detectable using Komada's medium. In addition, solarization is more economical than Pic-Clor 60. In 2008, Pic-Clor 60 cost $\sim \$ 2,100$ per acre when applied with polyethylene film. In comparison, 1 acre of polyethylene film cost $\sim \$ 1,200$ in the same year, although additional labor was required for manual installation. Cost of this installation may be minimized by use of mulch laying equipment. A further consideration with solarization is that production within the treated area must be idled for the duration of treatment. This inconvenience can be minimized by solarizing following a summer-harvested crop such as wheat. Finally, another advantage with solarization is the lack of environmental and safety regulations required for application of materials such as Pic-Clor 60. However, some issues may exist regarding disposal costs or recycling options for solarization films.

In summary, these results demonstrate two soil treatments, PicClor 60 and solarization, that are highly efficacious for treating localized areas with high concentrations of $F$. oxysporum $\mathrm{f}$. sp. vasinfectum race 4 inoculum. While Pic-Clor 60 and solarization may be too costly for routine management of Fusarium wilt in cotton, these treatments may be useful where race 4 is present. The severity of symptoms caused by race 4 and the ineffectiveness of management options available for other races, such as nematode control, make the problems posed by race 4 particularly intractable. Of the two treatments, solarization may be more economically practicable in areas where adequate soil temperatures (daily average of $40^{\circ} \mathrm{C}$ at $10-\mathrm{cm}$ depth) can be achieved. Ultimate adoption of this method in the production system of the San Joaquin Valley of California may depend on better understanding the factors controlling efficacy, such as the amount of applied water and duration of treatment that is necessary. Solarization would also be more attractive to growers if the benefits are observed for multiple years, as in a previous study (22). Lastly, the use of solarization in high-value crops grown in rotation with cotton may be warranted if other advantages, such as reductions in populations of persistent weed and nematode species, can be achieved $(9,33)$. Optimization of solarization to maximize benefits and minimize costs will require additional investigation.

\section{Acknowledgments}

We thank J. Salinas, N. Hudson, J. Penner, A. Mendez, D. Rogers, C. Ramos, P. Mungur, and A. Crump for field and laboratory assistance. TriCal, Western Farm Services, and Amvac generously provided materials and technical support for the fumigants. Delta and Pine Land Company and Phytogen provided seed.

\section{Literature Cited}

1. Armstrong, G. M., and Armstrong, J. K. 1960. American, Egyptian, and Indian cotton-wilt fusaria: Their pathogenicity and relationship to other wilt fusaria. U.S. Dep. Agric. Tech. Bull. 1219:1-19.

2. Bendavid-Val, R., Rabinowitch, H. D., Katan, J., and Kapulnik, Y. 1997. Viability of VA-mycorrhizal fungi following soil solarization and fumigation. Plant Soil 195:185-193.

3. Ben-Yephet, Y., Melero-Vera, J. M., and DeVay, J. E. 1988. Interaction of soil solarization and metam-sodium in the destruction of Verticillium dahliae and Fusarium oxysporum f. sp. vasinfectum. Crop Prot. 7:327-331.

4. Ben-Yephet, Y., Stapleton, J. J., Wakeman, R. J., and DeVay, J. E. 1987. Comparative effects of soil solarization with single and double layers of polyethylene film on survival of Fusarium oxysporum f. sp. vasinfectum. Phytoparasitica 15:181-185. 
5. Chellemi, D. O., Olson, S. M., Mitchell, D. J., Secker, I., and McSorley, R. 1997. Adaptation of soil solarization to the integrated management of soilborne pests of tomato under humid conditions. Phytopathology 87:250-258.

6. Chen, Y., and Katan, J. 1980. Effect of solar heating of soils by transparent polyethylene mulching on their chemical properties. Soil Sci. 130:271-277.

7. Davis, R. M., Colyer, P. D., Rothrock, C. S., and Kochman, J. K. 2006. Fusarium wilt of cotton: Population diversity and implications for management. Plant Dis. 90:692-703.

8. DeVay, J. E., Gutierrez, A. P., Pullman, G. S., Wakeman, R. J., Garber, R. H., Jeffers, D. P., Smith, S. N., Goodell, P. B., and Roberts, P. A. 1997. Inoculum densities of Fusarium oxysporum f. sp. vasinfectum and Meloidogyne incognita in relation to the development of fusarium wilt and the phenology of cotton plants (Gossypium hirsutum). Phytopathology 87:341346.

9. Elmore, C. L. 1991. Weed control by solarization. Pages 61-70 in: Soil Solarization. CRC Press, Inc., Boca Raton, FL.

10. Fernandez, D., Assigbetse, K., Dubois, M.-P., and Geiger, J.-P. 1994. Molecular characterization of races and vegetative compatibility groups in Fusarium oxysporum f. sp. vasinfectum. Appl. Environ. Microbiol. 60:40394046.

11. Freeman, M. F., and Tukey, J. W. 1950. Transformations related to the angular and the square root. Ann. Math. Statist. 21:607-611.

12. Garber, R. H., and Paxman, G. A. 1963. Fusarium wilt of cotton in California. Plant Dis. Rep. 47:398-400.

13. Gerik, J. S. 2005. Evaluation of soil fumigants applied by drip irrigation for liatris production. Plant Dis. 89:883-887.

14. Hamm, P. B., Ingham, R. E., Jaeger, J. R., Swanson, W. H., and Volker, K. C. 2003. Soil fumigant effects on three genera of potential soilborne pathogenic fungi and their effect on potato yield in the Columbia Basin of Oregon. Plant Dis. 87:1449-1456.

15. Hao, J. J., Yang, M. E., and Davis, R. M. 2009. Effect of soil inoculum density of Fusarium oxysporum f. sp. vasinfectum race 4 on disease development in cotton. Plant Dis. 93:1324-1328.

16. Hutmacher, R. B., Ulloa, M., Davis, R. M., Wright, S. D., Marsh, B., Goodell, P., Banuelos, G., Keely, M., and Munk, D. 2010. Assessment of Acala/Upland and Pima cottons response to Fusarium wilt disease in the San Joaquin Valley. Page 791 in: Proc. Beltwide Cotton Conf. National Cotton Counc. of America, New Orleans, LA.

17. Hyer, A. H., Jorgenson, E. C., Garber, R. H., and Smith, S. 1979. Resistance to root-knot nematode in control of root-knot nematode - Fusarium wilt disease complex in cotton. Crop Sci. 19:898-901.

18. Jacobsohn, R,, Greenberger, A., Katan, J., Levi, M., and Alon, H. 1980. Control of mulching Egyptian broomrape (Orobanchae egyptiaca) and other weeds by means of solar heating of the soil by polyethylene. Weed Sci. 28:312-316.

19. Jorgenson, E. C., Hyer, A. H., Garber, R. H., and Smith, S. N. 1978. Influence of soil fumigation on the fusarium-root-knot nematode disease complex of cotton in California. J. Nematol. 10:228-231.

20. Kappelman, A. J. 1983. Distribution of races of Fusarium oxysporum f. sp. vasinfectum within the United States. Plant Dis. 67:1229-1231.

21. Katan, J. 1981. Solar heating (solarization) of soil for control of soilborne pests. Annu. Rev. Phytopathol. 19:211-236.

22. Katan, J., Fishler, G., and Grinstein, A. 1983. Short- and long-term effects of soil solarization and crop sequence on Fusarium wilt and yield of cotton in Israel. Phytopathology 73:1215-1219.

23. Kim, Y., Hutmacher, R. B., and Davis, R. M. 2005. Characterization of California isolates of Fusarium oxysporum f. sp. vasinfectum. Plant Dis. 89:366-372.

24. Kirkpatrick, T. L., and Sasser, J. N. 1984. Crop rotation and races of Meloidogyne incognita in cotton root-knot management. J. Nematol. 16:323-328.

25. Komada, H. 1975. Development of a selective medium for quantitative isolation of Fusarium oxysporum from natural soil. Rev. Plant Prot. Res. 8:114-125.

26. Martin, F. N. 2003. Development of alternative strategies for management of soilborne pathogens currently controlled with methyl bromide. Annu. Rev. Phytopathol. 41:325-350.

27. McGovern, R. J., Vavrina, C. S., Noling, J. W., Datnoff, L. A., and Yonce, H. D. 1998. Evaluation of application methods of metam sodium for management of Fusarium crown and root rot in tomato in southwest Florida. Plant Dis. 82:919-923.

28. Netzer, D., Reuveni, R., and Dishon, I. 1980. Race identification and distribution of Fusarium wilt of cotton in Israel. Hassadeh 61:31-32.

29. Ogallo, J. L., Goodell, P. B., Eckert, J., and Roberts, P. A. 1997. Evaluation of NemX, a new cultivar of cotton with high resistance to Meloidogyne incognita. J. Nematol. 29:531-537.

30. Rich, J. R., and Bird, J. W. 1974. Association of early-season vesiculararbuscular mycorrhizae with increased growth and development of cotton Phytopathology 64:1421-1425.

31. Roberts, P. A. 1995. Conceptual and practical aspects of variability in rootknot nematodes related to host plant resistance. Annu. Rev. Phytopathol. 33:199-221.

32. Skovgaard, K., Nirenberg, H. I., O’Donnell, K., and Rosendahl, S. 2001. Evolution of Fusarium oxysporum f. sp. vasinfectum races inferred from multigene genealogies. Phytopathology 91:1231-1237.

33. Stapleton, J. J., and DeVay, J. E. 1983. Response of phytoparasitic and freeliving nematodes to soil solarization and 1,3-dichloropropene in California. Phytopathology 73:1429-1436.

34. Ulloa, M., Hutmacher, R. B., Davis, R. M., Wright, S. D., Percy, R., and Marsh, B. 2006. Breeding for Fusarium wilt race 4 resistance in cotton under field and greenhouse conditions. J. Cotton Sci. 10:114-127.

35. USDA Agricultural Marketing Service. 2008. Cotton varieties planted 2008 crop. USDA-AMS, Cotton Program, publ. mp_cn833.

36. Yang, M. E., Davis, R. M., and Hutmacher, R. B. 2006. Fusarium wilt of cotton in California: Characterization and PCR-based detection of race 4. Pages 93-96 in: Proc. Beltwide Cotton Conf. National Cotton Counc. of America, San Antonio, TX.

37. Zar, J. H. 1984. Biostatistical Analysis. 2nd ed. Prentice Hall, Englewood Cliffs, NJ. 